\title{
Maria Biolik
}

Uniwersytet Warmińsko-Mazurski w Olsztynie

\section{Uwagi o zbieraniu i budowie nazw terenowych}

Mikrotoponimia jest działem toponimii, który w ostatnich latach staje się coraz bardziej popularnym obszarem badawczym. Nazwy terenowe - pól, łąk, lasów, pastwisk, dołów, wzniesień, pagórków i podobnych obiektów - mają zasięg użycia ograniczony do wiejskiej wspólnoty komunikacyjnej, w której są tworzone i przekazywane pokoleniowo. W Polsce nazwy terenowe dotychczas nie zostały w całości zebrane i opisane, stanowią interesujący temat prac licencjackich, magisterskich i doktorskich. Kłopotliwe jest ich zebranie, ponieważ wymaga przeprowadzenia badań terenowych, wyszukania informatorów mieszkających od urodzenia w danej wsi i obeznanych z topografią terenu.

\section{Nazwa i jej warianty}

Pierwszym problemem wymagającym rozstrzygnięcia, na który napotyka badacz w czasie eksploracji terenowej jest ustalenie, czy dane określenie użyte przez informatora jest nazwą terenową czy apelatywnym określeniem miejsca. Pomocne mogą tu być metody proponowane przez onomastów i dialektologów, jak chociażby M. Kucałę w pracy Co już jest, a co jeszcze nie jest nazwa własna [Kucała 1967: 153-161] czy K. Dejnę, E. Rzetelską-Feleszko, H. Górnowicza, W. Lubasia, W. Śmiecha, M. Kornaszewskiego i innych badaczy [zob. Bibliografia]. Podczas rozmów w informatorami należy ustalić, czy dany obiekt posiada inne nazwy oboczne lub czy mieszkańcy używają wariantów danej nazwy własnej. Przykładowo, łąki na zachód od wsi Samborowo na Mazurach noszą dwie nazwy oboczne: Pod Drwęca i Za Samborowem, podane przez dwóch informatorów w tej samej wsi ${ }^{1}$. Zdarza się, że obiekt nosi różne nazwy oboczne używane w sąsiadujących miejscowościach. Utrwalenia wymagają również warianty

${ }^{1}$ Podane przykłady pochodzą głownie z mojej pracy Mikrotoponimia byłego powiatu ostródzkiego [Biolik 1994] oraz materiałów zbieranych do pisanych pod moim kierunkiem prac magisterskich przez studentów filologii polskiej UWM w Olsztynie. 
nazwy, formy gwarowe, np. pole ok. $1 \mathrm{~km}$ na wschód od Szyman (gm. Szczytno) zostało przez jednego informatora nazwane: Sztuki, inny podał nazwę Stuki $\mathrm{z}$ mazurzeniem $s / \check{\mathrm{s}}$. Zadaniem badacza podczas eksploracji terenowej jest ustalenie, czy podawane przez informatora określenia (nazwy oboczne i warianty) mają charakter apelatywny, czy też należą do grupy onimów. Podczas eksploracji terenowej ważne jest nie tylko zapisanie nazwy w formie gwarowej lub potocznej, lecz także zapisanie jej form fleksyjnych. Najczęściej w pracach z zakresu mikrotoponimii przytaczane są formy mianownika, dopełniacza i miejscownika.

\section{Obiekt i jego lokalizacja}

Uznanie przez badacza danego określenia za nazwę własną wymaga określenia rodzaju nazywanego obiektu oraz ustalenia jego dokładnej lokalizacji. Podczas badań terenowych należy również uzyskać od informatorów dodatkowe informacje dotyczące samej nazwy, pomocne w późniejszym ustaleniu jej etymologii i budowy (znaczenie motywacyjne) [Kornaszewski 1986: 6-7], np. las: Na Śmierdziuchu położony na północ od wsi Szymany jest związany z nazwą rowu Śmierdziuch, płynącego na zachód od wsi Nowiny. Nazwa Rów Pancerny używana we wsi Marksoby nawiązuje do umocnień wojskowych z okresu międzywojennego wzdłuż dawnej granicy z Polską. Nazwa pola Po Ostapiukach, leżącego ok. $2 \mathrm{~km}$ na północny zachód od wsi Wawrochy, pochodzi od nazwiska Ostapiuk - dawnego właściciela itd. Tego typu informacje uzyskane w terenie, a dotyczące znaczenia motywacyjnego danej nazwy są często zamieszczane w artykułach hasłowych nazw i służą późniejszej typologii semantyczno-motywacyjnej i strukturalno-gramatycznej.

\section{Nazwy dawne}

Opracowując mikrotoponimię danego obszaru, badacz nie powinien poprzestawać na informacjach uzyskanych $\mathrm{w}$ terenie, ale winien poszerzyć materiał badawczy o nazwy historyczne, używane przez dawnych mieszkańców wsi. Szczególnie dużo takich nazw obocznych noszą obiekty terenowe na Warmii i Mazurach, np. Lipowieckie Lasy leżące na południowy wschód od Szczytna dawniej nosiły nazwę Forst Reusswalde. Opracowanie mikrotoponimii danego obszaru wymaga analizy źródeł historycznych - wypisania z nich nazw zaginionych, nazw obocznych i ich wariantów zapisanych na mapach i w dokumentach oraz w zbiorach Komisji Ustalania Nazw Miejscowości i Obiektów Fizjograficznych².

${ }^{2}$ Są to częściowo opublikowane Urzędowe nazwy miejscowości i obiektów fizjograficznych, Warszawa 1963-1972. 
W dokumentach historycznych - opisach granic posiadłości, testamentach, podziałach majątków ziemskich, spisach robionych dla celów podatkowych - wymieniane są bardzo liczne nazwy lasów i zarośli, pól, poszczególnych ról i włók, nazwy granic i miedz, dróg, młynów, ogrodów, rzek i jezior. Aby stwierdzić, jak liczne są to nazwy, wystarczy przywołać pracę R. Mrózka opisującą system mikrotoponimiczny Śląska Cieszyńskiego w XVIII w., prace E. Rzetelskiej-Feleszko i J. Dumy z Pomorza, czy mazowieckie nazwy terenowe [Wolff, Rzetelska-Feleszko 1982].

Przydatność dokumentów historycznych w badaniach terenowych może uzasadniać fragment dokumentu opisujący powinności poddanych Klasztoru Wigierskiego z roku 1745: Wieś Białowierśnie czynszowa, włók 6. [...]. Podwoda z włoki para koni do Krolewca. Łąke Grębzdy z drugiemy wsiami sprzątnać i siano do klasztoru zwieść powinni. [...] Łąki w puszczy będace na uroczyskach Camry i Pręty wedtug dyspozycji klasztornej [...].

\section{Typologia nazw terenowych}

Zebrane nazwy terenowe wymagają opracowania. Zagadnienie klasyfikacji mikrotoponimów nie zostało jeszcze w polskiej toponimii do końca rozwiązane. Stosowane w różnych pracach klasyfikacje wynikają z przyjętych założeń metodologicznych [por. Jakus-Borkowa 1983; Górnowicz 1975, 1983, 1987; Biolik 2010, 2013], powinny jednak zawsze zachować jednolitość, kompletność i celowość kryteriów nadrzędnych oraz podkryteriów klasyfikacyjnych. Badacz - analizując materiał toponimiczny pod względem semantycznym lub formalnym - może utworzyć dowolną klasyfikację spełniającą te kryteria.

Często $\mathrm{w}$ pracach $\mathrm{z}$ zakresu mikrotoponimii stosowane są podziały semantyczno-motywacyjne (etymologiczne) i strukturalno-gramatyczne. Jeżeli chodzi o podział semantyczno-motywacyjny, to badacze najczęściej posługują się klasyfikacją W. Taszyckiego [Taszycki 1946], modyfikują tę klasyfikację lub stosują własne szczegółowe podziały znaczeniowe [Górnowicz 1983: 9]. Więcej problemów sprawia klasyfikacja strukturalno-gramatyczna. Jest to klasyfikacja formalna, analizująca mikrotoponimy jako jednostki gramatyczne o określonej strukturze morfologicznej. W pracach opisujących nazwy terenowe często stosowana jest klasyfikacja strukturalno-gramatyczna S. Rosponda, zawierająca podział nazw własnych na prymarne, sekundarne i komponowane.

Celem mojego opracowania jest wskazanie nazw własnych derywowanych słowotwórczo i niederywowanych, które w literaturze nie są interpretowane w sposób jednoznaczny, a tym samym mogą sprawiać kłopoty w ustalaniu ich budowy gramatycznej ${ }^{3}$ i zaliczeniu nazwy do właściwej grupy typologicznej.

${ }^{3}$ Próby analizy nazw terenowych podejmują historycy, dziennikarze i pedagodzy. Wymogiem niezbędnym podczas klasyfikacji formalnej (strukturalno-gramatycznej) toponimów jest znajomość 
Pod względem formalnym mikrotoponimy można dzielić różnie, w zależności od przyjętych własnych założeń metodologicznych. Można też analizować materiał badawczy, stosując podziały opracowane przez innych badaczy, np. wyodrębnić nazwy ze względu na liczbę wyrazów/składników, wydzielając grupę mikrotoponimów jedno- i wieloskładnikowych (wielowyrazowych) 4 .

Grupę mikrotoponimów jednoskładnikowych ${ }^{5}$ (jednowyrazowych) będą tworzyć nazwy prymarne - niederywowane słowotwórczo, równe już istniejącym wyrazom pospolitym lub innym nazwom własnym. Drugą strukturę nazewniczą mogą tworzyć derywaty nazwotwórcze. Będą to również mikrotoponimy jednoskładnikowe, według klasyfikacji S. Rosponda - nazwy sekundarne - a trzecią mikrotoponimy wieloskładnikowe, nazwane przez S. Rosponda nazwami złożonymi (composita) [Rospond 1957: 47], czyli ,zestawienia właściwe (typu Bliźnia Rola, Lipowski Grań, Trzycieskie Zarzecze), zestawienia prepozycyjne (typu Grapa nad Stawy, Odkrzas pod Krążelka, Plenisko w Równym), a także eliptyczne zestawienia adiektywne (typu Bukowa Mała) i eliptyczne nazwy prepozycyjne (typu Na Podlesiu, Na Kopaninę między Lasem)" [Mrózek 1990: 27].

\section{Procesy onimizacji i transonimizacji}

Nazwy jednoskładnikowe, prymarne, niederywowane słowotwórczo (derywowane semantycznie) mogły powstawać w wyniku onimizacji wyrazów pospolitych i transonimizacji nazw własnych oraz w wyniku redukcji (elipsa) składników w mikrotoponimach wieloskładnikowych.

Onimizacja, czyli przeniesienie gotowych tworów apelatywnych na płaszczyznę onimiczną, miała miejsce - przykładowo - w nazewniczych jednostkach substantywnych, takich jak wyraz pospolity góra > nazwa własna Góra; górka > Górka; zaścianek > Zaścianek.

W takich nazwach, jak: Rzeczka (: rzeczka), Rowek (: rowek), Dróżka (:dróżka), Dolinka (: dolinka), Stoczek (: stoczek) derywacja dokonała się na płaszczyźnie apelatywnej. Mały staw był określany stawkiem. Wyraz stawek został

zasad słowotwórstwa współczesnego języka polskiego i słowotwórstwa historycznego. Ważne jest także odróżnienie struktury nazwy od opisu sposobu jej powstania, ale pamiętać należy, że sposób utworzenia onimu ściśle łączy się z jego formą.

${ }^{4}$ Przy czym, jak pisze R. Mrózek, ,pojęcie składnika - któremu na płaszczyźnie apelatywnej odpowiada pojęcie wyrazu - wiąże się tu z segmentem językowej ekspozycji funkcji proprialnej” (Mrózek 1990: 27).

${ }^{5}$ Warstwę mikrotoponimów jednoskładnikowych współtworzą nazewnicze jednostki substantywne (typu Groblica, Kopanisko, Rosochacz, Odrzydołek) oraz eliptyczne twory adiektywne (typu Bukowa, Jatny, Zarabane); jedne i drugie w genetycznym rozwarstwieniu na nazwy prymarne, tzn. wyposażone w funkcję toponimiczną gotowe (formy) apelatywne i sekundarne, czyli derywaty nazwotwórcze" (Mrózek 1990: 27). 
przeniesiony na płaszczyznę onomastyczną, tworząc nazwę Stawek. W wielu pracach przyjmuje się, że jeżeli wyraz pospolity jest notowany w słownikach w tym samym znaczeniu, to nazwa własna utworzona w wyniku jego onimizacji będzie niederywowana słowotwórczo [Lubaś 1963: 207].

Transonimizacja ma miejsce wtedy, gdy istniejąca wcześniej nazwa własna zostanie wykorzystana do nazwania innego obiektu, np. imię Hanna < nazwa terenowa Hanna. Tak powstają nazwy własne obiektów terenowych równe nazwom osobowym: Hanna, Zośka, Kazimierz, Wojciech, Kopernik, Modzelewski. Niederywowane słowotwórczo struktury nazewnicze to również nazwy tzw. importowane lub przeniesione, np. Korea - pola leżące z dala od wsi, podobnie nazwy Betlejem, Ameryka, Syberia itd. [Borek 1988; Treder 1979, 1981; Bubak 1965, 1966].

Inną strukturą nazewniczą wśród jednoskładnikowych nazw niederywowanych słowotwórczo będą nazwy adiektywne: Kamienna, Kamienne, Dębowe, Gliniane, Księże, Pańskie, Wielbarskie, Spalone itd. Niektóre z nich mogły powstać na skutek elipsy członów określanych: Dobre < Dobre [Pole]; Kościelne < Kościelne [Pole]; Podleśna < Podleśna [Łąka] lub Wyrąbany [las], Spalony [las].

\section{Nazwy własne w liczbie mnogiej}

Do nazw jednoskładnikowych - prymarnych - niektórzy badacze zaliczają nazwy pluralne. Można je analizować jako niederywowane nazwotwórczo tylko wtedy, gdy udowodnimy, że zostały w formie liczby mnogiej przeniesione na płaszczyznę proprialną z płaszczyzny apelatywnej, np. rowki > Rowki; glinki > Glinki. Kategoria liczby jest cechą gramatyczną wyrazów pospolitych. Nazwy terenowe w swojej podstawowej funkcji referencyjnej występują tylko w liczbie pojedynczej - singulare tantum lub tylko w liczbie mnogiej - plurale tantum. Liczba mnoga w opozycji do liczby pojedynczej występuje w nazwiskach, gdyż oznaczają one albo jednego człowieka, np. Kowalski, albo rodzinę: Kowalscy [Cieślikowa 2002: 11-12]. W toponimii rzeczownik apelatywny w liczbie pojedynczej może zostać przeniesiony na płaszczyznę onimiczną, tworząc nazwę pluralną: brzoza > Brzozy; budzisko 'licha buda'> pole Budziska. Mamy wtedy do czynienia z derywacją paradygmatyczną. Jej przyczyną, obok innych czynników [Bal 1963: 171-194], może być prawo polaryzacji apelatywno-toponimicznej, polegające na tendencji do wytworzenia maksymalnej różnicy między wyrazem pospolitym a nazwą własną [Głuszczak 1972: 164].

Jako nazwy - derywowane paradygmatycznie poprzez zmianę kategorii liczby - trzeba analizować także nazwy terenowe motywowane przez inne nazwy własne, np. pole Podlipia (: n. wsi. Podlipie), Madziary (: nazwisko Madziar). 


\section{Derywaty nazwotwórcze (słowotwórcze)}

Mikrotoponimy jednoskładnikowe derywowane słowotwórczo to według S. Rosponda nazwy sekundarne, czyli derywaty nazwotwórcze. W. Lubaś zalicza tu nazwy „różniące się pod względem słowotwórczym i znaczeniowym od wyrazów pospolitych, terminów topograficznych i nazw etnicznych posiadaniem charakterystycznych formantów" [Lubaś 1963: 206]. W grupie nazw derywowanych nazwotwórczo można wydzielić różne struktury nazewnicze, np. ze względu na rodzaj derywacji. Najlepiej w pracach toponomastycznych została opisana derywacja sufiksalna, jako najbardziej charakterystyczna w słowotwórstwie nazw polskich.

Analiza każdej nazwy własnej derywowanej sufiksalnie jest zależna od podanej podstawy derywacyjnej (motywacyjnej), np. nazwa pola Kobylak może być derywowana sufiksem - ak od wyrazu kobyta (z wymianą $l: \ell$ ), uzasadniona informacją, że 'na polu pasła się kobyła'; od przezwiska Kobyła 'pole było/jest własnością człowieka, którego przezywają Kobyła'; od nazwiska Kobylarz po dezintegracji podstawy Kobyl[arz] lub niederywowana od nazwiska Kobylak. Nazwa rzeki Leśnica może być derywowana sufiksem -nica (z wymianą 'e : 'a, $s: s ́$ ) od wyrazu las 'bo płynie przez las' lub sufiksem -ica (z wymianą $n: \dot{n}$ ) od przymiotnika leśny. Nazwa lasu Lipowiec może być derywatem utworzonym za pomocą sufiksu -owiec od lipa lub nazwiska Lip[ski] przy parafrazie 'lasek przy siedlisku Lipskiego' albo za pomocą sufiksu -ec od przymiotnika lipowy (z wymianą $w: w$ ') lub nazwiska Lipowski przy motywacji 'bo zalesiono pole, którego właścicielem był Lipowski' (Lipow[ski], po jej dezintegracji z wymianą $w: w$ ').

To, do jakiej struktury nazewniczej zostanie zaliczona nazwa derywowana sufiksalnie, zależy od jej motywacji (podstawy nazwotwórczej - motywującej nazwę). Dobrze jest wskazać towarzyszące derywacji wymiany morfologiczne (samogłoskowe i spółgłoskowe) oraz ucięcia (dezintegracje) podstaw derywacyjnych. W nazwach własnych, podobnie jak w wyrazach pospolitych, zachodziły procesy asymilacji, powodując ich leksykalizację, np. opisując nazwę: Kozacka od kozak z motywacją 'kozacy rozbijali tam obozy', trzeba wydzielić sufiks -ska, podobnie jak w nazwisku Piwnicki od piwnica [Biolik 2001: 5-19].

\section{Nazwy terenowe od wyrażeń przyimkowych}

Podstawą mikrotoponimów jednoskładnikowych derywowanych słowotwórczo mogą być wyrażenia przyimkowe. Analizując bardzo produktywne w mikrotoponimii struktury nazewnicze, takie jak Podlesie, Padgaje, Podskale, Podrzecze, Podbrzezie, Poddębie, Podlipie, należy pamiętać, że zostały one derywowane historycznym sufiksem *-bje > 'e: Podgórze (: pod góra z wymianą $r: r z$ ). Na skutek zmian zachodzących w języku polskim sufiks uległ ściągnięciu 
*-bje > 'e, stając się końcówką fleksyjną, która pełni funkcję formantu. Rzeczowniki pochodne od wyrażeń syntaktycznych poddasze (: pod dachem), bezdroże (: bez drogi) są w gramatykach współczesnego języka polskiego zaliczane do derywatów paradygmatycznych [Grzegorczykowa 1979: 58]. Nazwy własne: Podbuże (: pod Bugiem, rzeka Bug), Podróże (: pod Różem, rzeka Róż), Podgóra (: pod góra), Podlas (: pod lasem), Podryn (: pod Rynem, wieś Ryn), podobnie jak podane wyżej wyrazy pospolite, należy zaliczyć do derywatów paradygmatycznych z formantami odpowiednio: - 'e, $-a$, $-\varnothing$. Zawsze ważna jest podstawa motywacyjna, np. nazwę Zagaj można uznać za niederywowaną słowotwórczo przy motywacji wyrazem gwarowym zagaj 'zagajnik' lub za derywowaną formantem -ø od podstawy 'za gajem'.

\section{Nazwy terenowe derywowane paradygmatycznie}

Derywaty paradygmatyczne, w których funkcję formantów pełnią końcówki fleksyjne stanowią produktywną strukturę nazewniczą. Tworzą ją struktury $\mathrm{z}$ formantem -ø jako tzw. derywaty wsteczne, np. Biel od czasownika bielić oraz liczne struktury nazewnicze o charakterze posesywnym, zwane dopełniaczowymi, które wskazują na przynależność obiektu do osoby, np. formant -i/-y Bronki (: imię Bronka z wymianą $k: k^{\prime}$ lub Bronek z wymianą e : -ø i $k: k^{\prime}$ ); Marynki (: Marynka); Anny (: Anna), Kowalichy (: kowalicha 'żona kowala), -a: Antoniuka (: nazwisko Antoniuk), Józia (: Józio). Grupę mikrotoponimów paradygmatycznych powiększają struktury nazewnicze z formantami: -ich Modzelewskich (:Modzelewscy), -ej Czerniakowej (: Czerniakowa 'żona Czerniaka'), Adamowej (: Adamowa 'żona Adama'), -ego Krajewskiego (: Krajewski).

\section{Nazwy terenowe $z$ formantem -ow-}

Przy toponimach z formantem -ów (końcówka dopełniacza liczby mnogiej), np. Antoniuków (: Antoniuki), Augustów (: Augusty), Bartników (: Bartniki), Franków (: Franki), można przyjąć za S. Rospondem, że końcówka fleksyjna dopełniacza $^{6}$ stała się morfemem słowotwórczym i pełni funkcje identyczne jak przyrostek dzierżawczy -ów, -owa, -owe [Rospond 1971: 143], por. np. synowa 'żona syna' i określenia apelatywne: pole synowej lub pole syna, synowe pole oraz pole synów (np. dwóch). Model nazewniczy nazw terenowych derywowanych za pomocą

\footnotetext{
${ }^{6}$ Są to formanty utworzone z końcówek fleksyjnych. S. Rospond określa je mianem morfemów słowotwórczych i mianem formantów. Nie będzie błędem uważanie nazw zakończonych na -ów: Antoniuków (: Antoniuki), Janów (: Jany, to jest Jan i jego rodzina) jako derywowanych paradygmatycznie z formantem -ów.
} 
sufiksu -ów można wskazać np. w nazwie Kowalów przy motywacji 'pole przy domu kowala' czy Lipów 'pole, na którym rośnie lipa', Przejazdów od przejazd, 'bo ludzie przejeżdżają przez to pole'.

Tylko na podstawie parafrazy można rozstrzygnąć, czy mamy do czynienia z derywacją sufiksalną czy paradygmatyczną, np. nazwę lasu Dębowo przy motywacji 'rosną tam dęby'(: $d a b)$ uznamy za derywowaną sufiksalnie, a przy motywacji przymiotnikiem dębowy za derywowaną paradygmatycznie [Kęsikowa 1976: 187).

Nazwę Wójtowa można analizować jako - jednoskładnikową, niederywowaną, adiektywną - równą przymiotnikowi w rodzaju żeńskim wójtowa, por. wójtowy 'przymiotnik od wójt' lub w przypadku parafrazy motywacyjnej 'łąka przy domu wójta' jako nazwę derywowaną za pomocą sufiksu -owa. Sufiks -owy można wydzielić w nazwie: Adamkowy (: Adamek/Adamko), sufiks -owo w nazwach pól: Cyganowo (: Cygan), Adamowo (: imię Adam), Bąkowo (: nazwa osobowa $B a k$ ) itd., ale nazwę pola Kowalowe przy parafrazie 'pole przy domu kowala' można zaliczyć do derywowanych za pomocą sufiksu -owe od rzeczownika kowal lub utworzoną w wyniku onimizacji przymiotnika kowalowe.

Nazwy terenowe mogły być tworzone także za pomocą sufiksów: -ow-ski, -ow-ska, -ow-skie, np.: Pisarzowski (: pisarz), Kocurowski (: nazwisko Kocur), Wójtowskie (: wójt), Krzysztofowska (: Krzysztof) [Breza 1978: 95-119; Biolik 2009: 71-79], mogły też powstawać na skutek elipsy członów utożsamiających wcześniejszych nazw komponowanych - dwuskładnikowych, np. Wójtowa (:Wójtowa [Łąka], Baltazarowska (: Baltazarowska [wtóka, ziemia]).

Jednoskładnikowe nazwy derywowane sufiksalnie mogły być tworzone także na skutek uniwerbizacji nazw wieloskładnikowych, jak np. Danielówka za pomocą sufiksu -ka od Danielowe [pole] lub Danielówka od [pole] Daniela sufiksem -ówka.

\section{Derywacja wymienna w mikrotoponimii}

W mikrotoponimii można spotkać mało produktywne derywaty utworzone za pomocą derywacji wymiennej. Jej przykładem może być nazwa Podlaś od nazwiska Podleś z wymianą e na $a$ czy nazwa pola Burak od nazwiska Bulak.

\section{Mikrotoponimy wieloskladnikowe}

W typologii nazw terenowych ważne miejsce zajmują nazwy wieloskładnikowe, nazywane złożonymi (nazwy komponowane). Nazwy te najczęściej nie sprawiają kłopotów podczas ich analizy strukturalnej. Są to tzw. dwuskładnikowe zestawienia właściwe, złożone z: 
a) przymiotnika i rzeczownika, typu: Dobry Las, Dalekie Pola, Mokre Eqki, Biała Droga, Ciemny Lasek, Czerwony Most. Do grupy tej należą również nazwy, w których człon pierwszy jest przymiotnikiem utworzonym od nazwy własnej, np. nazwy miejscowości: Lemańskie Lasy (: wieś Lemany), Lipowieckie Lasy (: wieś Lipowiec);

b) rzeczownika i przymiotnika: Aleja Brzozowa, Droga Lipowska, Droga Marksowska, Droga Pużarska, Droga Strachów, Górka Szkolna, Ląki Gburskie (: gbur 'bogaty gospodarz');

c) rzeczownika i rzeczownika: Olszyna Jarka, Góra Czarownicy, Schronisko Dzików, Ścieżka Torami;

d) rzeczownika i wyrażenia przyimkowego w funkcji przydawki: Droga do Jabłonki, Droga na Sędrowo, Droga nad Granice, Laka od Rogalska, Pole na Glinkach, Jesion na Górce, Łąki na Lizaku, Łąki na Rokitce, Pole koło Muchy, Las koło Krzyża, Las koło Murzyna, Łąki po Rydlu, Pole pod Martą;

e) przymiotnika i przymiotnika: Bukowa Mała, Leszczynowa Stara;

f) liczebnika i rzeczownika: Trzy Włóki, Cztery Pręty, Siedem Morgów lub rzeczownika i liczebnika: Parowa Pierwsza itd. [Kurek 1986: 59-85].

Do grupy nazw komponowanych należy zaliczyć nazwy terenowe w postaci wyrażeń przyimkowych. Są to bardzo liczne wśród nazw terenowych tzw. eliptyczne nazwy prepozycyjne, najczęściej określające położenie nazywanego obiektu względem jakiegoś innego obiektu lub miejsca w terenie. Pierwotnie były to wyrażenia apelatywne, które poprzez zmianę funkcji stały się nazwami własnymi, np. pole pod lasem > Pod Lasem, por. inne nazwy: Koło Drogi, Za Lasem, Za Młynem, Za Okopami, Za Pieńkosem. Licznie tworzone są też nazwy wskazujące na wcześniejszą przynależność obiektu, np.: Po Kopaczu, Na Blochowe, Na Brzózkowym, Po Dawidzie, Po Florczakach. Nazwy terenowe od wyrażeń przyimkowych były wielokrotnie analizowane i literatura na ich temat jest bogata [Tomaszewska 1996; Rzetelska-Feleszko 1982].

\section{Wnioski}

Uznanie przez badacza określenia obiektu terenowego za nazwę własną wymaga podania lokalizacji nazywanego obiektu oraz uzyskania dodatkowych informacji o motywacji, znaczeniu i budowie nazwy. Nazwy terenowe są najczęściej opisywane pod względem semantyczno-etymologicznym i strukturalno-gramatycznym. Klasyfikacje stosowane do opisu nazw terenowych powinny umożliwiać jednolity podział materiału według wcześniej ustalonych kryteriów. Analizując nazwy własne, należy pamiętać o historycznych procesach językowych, które zachodziły w dialektach i polskim języku ogólnym. 


\section{Bibliografia}

Bal Józef, 1963, Niemotywowane pluralis niektórych nazw miejscowych, „Onomastica” VIII, 171-194.

Biolik Maria, 1994, Mikrotoponimia byłego powiatu ostródzkiego, Olsztyn.

Biolik Maria, 2001, Zmiany morfemiczne w nazwiskach polskich na -ski (Leksykalizacja, perintegracja i absorpcja morfologiczna), „Prace Językoznawcze” III, Olsztyn, 5-19.

Biolik Maria, 2009, Funkcja identyfikacyjna nazw własnych $w$ dobrach kamedutów wigierskich na Suwalszczyźnie w XVII wieku, [w:] Polszczyzna Mazowsza i Podlasia, t. XIII: Językowa przeszłość i wspótczesność Mazowsza i Podlasia, Łomża, 71-79.

Biolik Maria, 2010, Tendencje nazewnicze w rozwoju nazw terenowych ladowych na Mazurach po 1945 r. (na podstawie nazw z powiatu szczycieńskiego), „Onomastica” LIV, 109-120.

Biolik Maria, 2013, Analiza strukturalno-gramatyczna mikrotoponimów (na przykładzie nazw terenowych gminy Kolno w województwie podlaskim), „Prace Językoznawcze”, Olsztyn, 17-30.

Borek Henryk, 1988, Nazwy relacyjne w toponimii, [w:] Karol Zierhoffer (red.), V Ogólnopolska Konferencja Onomastyczna. Księga referatów, Poznań, 43-51.

Breza Edward 1978, Nazwy terenowe typu Bonikowski (Plac), Klepinowski (Dom) na Pomorzu Gdańskim, „Onomastica” XXIII, 95-119.

Bubak Józef, 1965, 1966, Nazwy przeniesione w polskiej toponomastyce, „Onomastica” X, 50-73; XI, 43-61.

Cieślikowa Aleksandra (red.), 2002, Mały słownik odmiany nazw własnych, Kraków.

Dejna Karol, 1956, Terenowe nazwy śląskie, „Onomastica” II, 103-126.

Głuszczak Juliusz, 1972, Pluralne nazwy topograficzne typu Wierzby, Góry, „Rozprawy Komisji Językowej. Wrocławskie Towarzystwo Językowe", VIII, 145-167.

Górnowicz Hubert, 1975, Ze studiów nad toponomastyka Pomorza Gdańskiego, t. IV: Nazwy terenowe $i$ wodne z suf. -ica i jego pochodnymi, „Onomastica” XX, 35-78.

Górnowicz Hubert, 1983, Nazwy terenowe i ich podziat wewnętrzny, [w:] Kazimierz Rymut (red.), $7-17$.

Górnowicz Hubert, 1987, Nazwy geograficzne Pomorza Gdańskiego typu: Podlas, Przybrody, „Onomastica” XXXII, 55-63.

Grzegorczykowa Renata, 1979, Zarys stowotwórstwa polskiego, Warszawa.

Jakus-Borkowa Ewa, 1983, Budowa mikrotoponimów Pomorza Gdańskiego, „Zeszyty Naukowe Wydziału Humanistycznego Uniwersytetu Gdańskiego. Prace Językoznawcze" 9, Gdańsk, $47-57$.

Karaś Mieczysław, 1955, Nazwy miejscowe typu Podgóra, Zalas w języku polskim i innych językach stowiańskich, „Prace Onomastyczne” 1, Wrocław.

Kęsikowa Urszula, 1976, Nazwy geograficzne Pomorza Gdańskiego z sufiksem -ov-, „Pomorskie Monografie Toponomastyczne" 2, Gdańsk.

Kornaszewski Marek, 1986, W sprawie klasyfikacji nazw terenowych. Uwagi i propozycje, „Onomastica" XXX, 5-15.

Kucała Marian, 1967, Co już jest, a co jeszcze nie jest nazwa własna, „Onomastica” XII, 153-161.

Kurek Halina, 1986, Odliczebnikowe nazwy terenowe w języku polskim, „Onomastica” XXXI, 59-86.

Lubaś Władysław, 1963, 1964, Nazwy terenowe powiatów jasielskiego i krośnieńskiego, „Onomastica" VIII, 195-236; IX, 123-163.

Mrózek Robert, 1990, System mikrotoponimiczny Śląska Cieszyńskiego XVIII wieku, Katowice.

Mrózek Robert, 1998, Nazwy terenowe, [w:] Ewa Rzetelska-Feleszko (red.), Polskie nazwy własne. Encyklopedia, Kraków-Warszawa, 231-232.

Rospond Stanisław, 1957, Klasyfikacja strukturalno-gramatyczna słowiańskich nazw geograficznych, Wrocław. 
Rospond Stanisław, 1971, Gramatyka historyczna języka polskiego, Warszawa.

Rymut Kazimierz (red.), 1983, Geografia nazewnicza. Materiaty z VII Konferencji Onomastyki Stowiańskiej przy Międzynarodowym Komitecie Slawistów i II posiedzenia Komisji Onomastycznej Komitetu Językoznawstwa PAN, Mogilany, 23-25 IX 1980 r., Wrocław-Warszawa-Kraków-Gdańsk-Łódź.

Rzetelska-Feleszko Ewa, 1983, Nazwy terenowe od wyrażeń przyimkowych, „Studia z Filologii Polskiej i Słowiańskiej” 21, 85-101.

Rzetelska-Feleszko Ewa, Duma Jerzy, 2008, 2013, Nazwy terenowe Pomorza Zachodniego zawierajace elementy stowiańskie, t. I, II, Warszawa.

Śmiech Witold, 1983, Stosunek polskich nazw terenowych do wyrazów pospolitych, [w:] Kazimierz Rymut (red.), 37-51.

Taszycki Witold, 1946, Stowiańskie nazwy miejscowe. Ustalenie podziału, Kraków; przedruk [w:] idem, 1958, Rozprawy i studia polonistyczne, t. I: Onomastyka, Wrocław-Kraków, 228268.

Tomaszewska Sławomira, 1996, Polskie mikrotoponimy motywowane wyrażeniami przyimkowymi, Łódź.

Treder Jerzy, 1979, Nazwy ponowione wśród nazw przeniesionych, „Onomastica” XXIV, 19-43.

Treder Jerzy, 1981, Nazwy importowane w toponimii Kaszub, „Onomastica” XXVI, 61-81.

Wolff Adam, Rzetelska-Feleszko Ewa, 1982, Mazowieckie nazwy terenowe do końca XVI wieku, Warszawa.

\section{Maria Biolik}

\section{Notes on the collection and construction of field names}

\section{(Summary)}

The analysis of structural and grammatical field name has not been fully described in Polish word-formation. In the case of difficult names, which in literature are not interpreted straightforwardly, it is not easy to determine their grammatical structure. When it comes to derivate names, it is very important to identify its appellative or onomastic derivational form as well as the type of processes that occur in language.

Slowa kluczowe: onomastyka, nazwy terenowe, derywacja, kompozycja, wyrażenie przyimkowe.

Key words: onomastics, field names, derivation, composition, prepositional phrase. 